Acta Universitatis Wratislaviensis No 3705

PRAWO CCCXX

Wrocław 2016

DOI: $10.19195 / 0524-4544.320 .4$

WITOLD MAŁECKI

Uniwersytet Wrocławski

e-mail: witold.malecki@prawo.uni.wroc.pl

\title{
Uwagi w sprawie publicznoprawnej determinacji ram przedmiotowych publicznego prawa gospodarczego
}

Istotą transformacji kategorii administracyjnego prawa gospodarczego w kategorię publicznego prawa gospodarczego, która dokonała się w nauce polskiej na przestrzeni ostatnich lat ${ }^{1}$, wydaje się ujęcie jako płaszczyzny wyodrębniania norm prawnych dotyczących problematyki gospodarczej sfery prawa publicznego w miejsce prawa administracyjnego. Jej następstwem wynikającym z szerszego niż w przypadku prawa administracyjnego kształtu granic prawa publicznego powinno stać się, odpowiadające zakresowi wyznaczonemu nową nazwą, rozszerzenie ram przedmiotowych publicznego prawa gospodarczego w stosunku do administracyjnego prawa gospodarczego ${ }^{2}$. Realizacja założenia o adekwatności zakresu przedmiotowego publicznego prawa gospodarczego do brzmienia na-

1 Szczególną rolę w kształtowaniu koncepcji publicznego prawa gospodarczego odegrała prof. Teresa Rabska — do jej najważniejszych opracowań dotyczących tej tematyki zaliczyć należy Rozwój nauczania publicznego prawa gospodarczego — przyczynek do dyskusji, „Przegląd Ustawodawstwa Gospodarczego" 2005, nr 9; Prawo administracyjne a publiczne prawo gospodarcze (kilka dyskusyjnych refleksji), [w:] Między tradycją a przyszłościa w nauce prawa administracyjnego. Księga jubileuszowa dedykowana Profesorowi Janowi Bociowi, red. J. Supernat, Wrocław 2009; Refleksje nad nauka publicznego prawa gospodarczego, „Roczniki Nauk Prawnych” 2011, nr 1.

2 Pogląd o braku tożsamości między administracyjnym prawem gospodarczym i publicznym prawem gospodarczym jest szeroko ugruntowany w doktrynie. Odmienne stanowisko wydaje się zajmować J. Olszewski, wskazując na zamienność przywołanych pojęć - Publiczne prawo gospodarcze, red. J. Olszewski, Warszawa 2015, s. 4. 
zwy tego działu prawa ${ }^{3}$ budzi jednak zasadnicze wątpliwości na tle analizy treści publikowanych współcześnie opracowań w zamierzeniu całościowo przedstawiających zagadnienia publicznego prawa gospodarczego ${ }^{4}$. Określenie zakresu przedmiotowego publicznego prawa gospodarczego ujmowanego przez autorów wskazanych opracowań w sposób zbliżony nie zostało bowiem (w większości przypadków) odniesione do przesłanek systemowych wymagających ustalenia zakresu przedmiotowego z uwzględnieniem granic zdefiniowanych wyznacznikami zawartymi w nazwie tego działu prawa — ,publiczne” oraz „gospodarcze”.

Brak systemowego odniesienia dla konstruowania zakresu przedmiotowego publicznego prawa gospodarczego wywoływać może konfuzję dostrzegalną szczególnie wyraźnie na tle konotacji systemowej nazwy tego działu prawa z okresu poprzedzającego transformację - ,administracyjne prawo gospodarcze”. Wyznacznik ,administracyjne” implikował objęcie zakresem przedmiotowym wskazanego działu prawa norm dotyczących problematyki gospodarczej w obrębie prawa administracyjnego stanowiącego jedną z podstawowych gałęzi prawa - zasadniczych jednostek klasyfikacyjnych systemu prawa ${ }^{5}$. Jak wskazano powyżej, a priori uzasadnione mogłoby więc wydawać się uznanie za konsekwencję zamiany wyznacznika ,administracyjne” na „publiczne” zastąpienie prawa administracyjnego - jako płaszczyzny wyodrębniania norm o problematyce gospodarczej - prawem publicznym. Kształt zakresu przedmiotowego publicznego prawa gospodarczego prezentowany we współczesnej literaturze hipotezy tej jednak nie potwierdza. Zakresem przedmiotowym publicznego prawa gospodarczego nie zostały objęte bowiem normy dotyczące problematyki gospodarczej pozostające $\mathrm{w}$ obrębie gałęzi prawa o charakterze bezsprzecznie publicznoprawnym - na czele z normami prawa karnego gospodarczego ${ }^{6}$. Próżno szukać w zakresie tym również m.in. norm

${ }^{3}$ Nie jest celem niniejszego opracowania analiza gałęziowego charakteru publicznego prawa gospodarczego. Dla jego pozycji w systemie prawa wykorzystane zostanie więc neutralne określenie „dział prawa”.

4 Przedmiotem odniesienia w ramach niniejszego opracowania, jako publikowane współcześnie opracowania w zamierzeniu całościowo przedstawiające zagadnienia publicznego prawa gospodarczego, będą wydane w bieżącej dekadzie (od 2010 r.) opracowania o charakterze podręcznikowym - C. Kosikowski, Publiczne prawo gospodarcze Polski i Unii Europejskiej, Warszawa 2010; T. Demendecki, Zarys polskiego prawa publicznego gospodarczego, Lublin 2011; K. Strzyczkowski, Prawo gospodarcze publiczne, Warszawa 2011; Z. Snażyk, A. Szafrański, Publiczne prawo gospodarcze, Warszawa 2013; Publiczne prawo gospodarcze. Zarys wyktadu, red. R. Blicharz, Warszawa 2015; Publiczne prawo gospodarcze, red. J. Olszewski, Warszawa 2015, Prawo gospodarcze publiczne, red. A. Powałowski, Warszawa 2015, a także opracowanie: Publiczne prawo gospodarcze, Warszawa 2013, („System Prawa Administracyjnego”, t. 8a i 8b, red. J. Grabowski, L. Kieres, A. Walaszek-Pyzioł).

${ }^{5}$ L. Kieres, [w:] A. Borkowski et al., Administracyjne prawo gospodarcze, Wrocław 2009, s. 11.

6 J. Nowacki, Prawo publiczne - prawo prywatne, Katowice 1992, s. 67. 
prawa podatkowego związanych z podejmowaniem i wykonywaniem działalności gospodarczej ${ }^{7}$.

Rozbieżność między kształtem zakresu przedmiotowego publicznego prawa gospodarczego prezentowanym we współczesnych opracowaniach a supozycjami natury systemowej wynikającymi z brzmienia nazwy ,publiczne prawo gospodarcze" skłania do refleksji w przedmiocie znaczenia, jakie należy przypisać członowi „publiczne” w odniesieniu do stanowisk prezentowanych we współczesnych opracowaniach. Zamierzeniem niniejszego opracowania będzie wyróżnienie teoretycznych modeli relacji wyznacznika ,publiczne” do zakresu przedmiotowego publicznego prawa gospodarczego, a także określenie modelu w stopniu najwyższym odpowiadającego kształtowi zakresu przedmiotowego publicznego prawa gospodarczego prezentowanego w literaturze. Refleksja ta pozwoli rozstrzygnąć, w czym tkwi sens ujęcia członu ,publiczne” w nazwie działu prawa ,publiczne prawo gospodarcze".

\section{II}

Pierwszym poddanym analizie modelem teoretycznym relacji wyznacznika „publiczne” do zakresu przedmiotowego publicznego prawa gospodarczego będzie model kształtujący. W modelu tym wyznacznikowi „publiczne” przypisać należy rolę determinującą, określającą zakres przedmiotowy publicznego prawa gospodarczego, kreującą jego ramy. Zakres przedmiotowy obejmowałby przeto cały obszar wydzielony w systemie prawa na podstawie wyznacznika ,publiczne”, wraz z drugim współkształtującym go wyznacznikiem „gospodarcze”.

W oparciu o precedencję wskazanych wyznaczników wyróżnić należy dwa warianty modelu kształtującego. W pierwszym z wariantów za prymarny uznany zostałby wyznacznik ,publiczne”, wobec czego status uniwersum, pierwotnej płaszczyzny wydzielania publicznego prawa gospodarczego, przypisać wypadłoby prawu publicznemu. W obszarze tym, przy zastosowaniu wyznacznika pomocniczego „gospodarcze”, wydzielona zostałaby podsfera obejmująca zagadnienia dotyczące problematyki gospodarczej ${ }^{8}$. Zakres przedmiotowy publicznego prawa gospodarczego, determinowany wyznacznikami zawartymi w nazwie działu prawa, obejmowałby w przedstawionym ujęciu ogół norm prawa publicznego dotyczących problematyki gospodarczej. Jakkolwiek z uwagi na brak powszechnie

7 Warto jednak zaznaczyć, że zagadnienia podatkowe zostały uwzględnione w jednym z podręczników administracyjnego prawa gospodarczego, zob. S. Hoc, Prawo administracyjne gospodarcze. Wybrane zagadnienia, Warszawa 2009, s. 161-163.

8 O gospodarowaniu jako dziedzinie działalności człowieka regulowanej prawem gospodarczym zob. Z. Snażyk, A. Szafrański, op. cit., s. 3-4. 
uznawanych kryteriów wydzielania prawa publicznego ${ }^{9}$ precyzyjne określenie granic przedmiotowych publicznego prawa gospodarczego nie wydawałoby się możliwe, zawierałyby się w nich bezsprzecznie ,zespoły norm wyspecjalizowanych tematycznie" $10 \mathrm{w}$ odniesieniu do działalności gospodarczej w obrębie działów prawa o niekwestionowanym publicznoprawnym charakterze, a zatem, obok stanowiących trzon publicznego prawa gospodarczego norm administracyjnego i konstytucyjnego prawa gospodarczego ${ }^{11}$, m.in. normy prawa karnego gospodarczego i normy dotyczące problematyki gospodarczej z zakresu prawa międzynarodowego publicznego.

Godzi się zauważyć, że w przedstawionym ujęciu publiczne prawo gospodarcze należałoby uznać za dział prawa o charakterze quasi-kompleksowym. Jak wskazuje się w literaturze, przesłankami wyodrębniania kompleksowych gałęzi prawa są jednolitość przedmiotu normowania w ich ramach oraz różnorodność występujących w nich metod regulacji ${ }^{12}$. O ile jednolitość przedmiotowa nie wydaje się budzić wątpliwości w odniesieniu do publicznego prawa gospodarczego, o tyle ex definitione nie będzie $\mathrm{w}$ jego ramach znajdować zastosowania jedna $\mathrm{z}$ metod regulacji - metoda cywilnoprawna (prywatnoprawna). Wyłączenie to każe więc postrzegać publiczne prawo gospodarcze jako dział o charakterze kompleksowym nie w pełnym stopniu.

Ukształtowanie zakresu przedmiotowego publicznego prawa gospodarczego według modelu kształtującego, w wariancie uznającym za pierwotną dla wyodrębniania tego działu prawa płaszczyznę prawa publicznego niewątpliwie nie znajduje odzwierciedlenia we współczesnej literaturze. O ile normy prawa międzynarodowego są niekiedy omawiane przez autorów opracowań w zamierzeniu całościowo przedstawiających zagadnienia publicznego prawa gospodarczego ${ }^{13}$, o tyle w opracowaniach tych próżno szukać choćby skromnego odwołania do regulacji prawnokarnych. Nie wydaje się, aby uzasadnienia pominięcia omówienia choć podstawowych zagadnień z zakresu prawa karnego gospodarczego należało dopatrywać się w dążeniu do rozłącznego ujmowania treści dydaktycznych przedstawianych w ramach opracowań dotyczących poszczególnych działów prawa. W przypadku opracowań poświęconych kompleksowym gałęziom prawa, takim

9 Szereg kryteriów podziału prawa na publiczne i prywatne poddaje analizie J. Nowacki idem, op. cit., s. 71-105.

10 Pojęciem tym posługuje się J. Grabowski, por. idem, [w:] Publiczne prawo gospodarcze, t. 8 a, s. 19 .

11 Niektórzy autorzy ujmują publiczne prawo gospodarcze jako sumę administracyjnego prawa gospodarczego i konstytucyjnego prawa gospodarczego, zob. K. Strzyczkowski, op . cit., s. 52; Z. Snażyk, A. Szafrański, op. cit., s. 3. Konstytucyjne publiczne prawo gospodarcze szeroko charakteryzuje L. Kieres, por. idem, Konstytucyjne publiczne prawo gospodarcze, „Ruch Prawniczy, Ekonomiczny i Socjologiczny" 2014, nr 2, s. 191-213.

12 S. Wronkowska, Podstawowe pojęcia prawa i prawoznawstwa, Poznań 2005, s. 117.

13 M.in. Prawo gospodarcze publiczne..., s. 51 n., K. Strzyczkowski, op. cit., s. 476 n. 
jak prawo pracy czy prawo wyznaniowe, nader częste jest bowiem ujmowanie adekwatnych przedmiotowo norm prawnokarnych ${ }^{14}$. Uznanie publicznego prawa gospodarczego za dział o charakterze quasi-kompleksowym, obejmujący ogół norm prawa publicznego dotyczących problematyki gospodarczej, wymagałoby więc uwzględnienia w jego ramach przedmiotowych również przepisów prawa karnego odnoszących się do przestępstw wyodrębnionych ze względu na przedmiot dotyczący gospodarki - ten zbiór norm prawnokarnych, jak wstępnie sygnalizowano powyżej, przyjęto zaś nazywać „prawem karnym gospodarczym”. Zgodnie z ustaleniami przyjętymi na XIII Kongresie Międzynarodowego Stowarzyszenia Prawa Karnego (AIDP), przeprowadzonym w 1984 r. w Kairze, za prawo karne gospodarcze uznano ,przepisy zawierające przestępstwa przeciwko porządkowi gospodarowania, w szczególności - reguły ustanowione przez państwo w sferze działalności gospodarczej”"15.

\section{III}

W drugim wariancie kształtującego modelu relacji wyznacznika „publiczne” do zakresu przedmiotowego publicznego prawa gospodarczego wyznacznikowi „publiczne” należałoby przypisać znaczenie pomocnicze, znaczenie zaś prymarne - wyznacznikowi ,gospodarcze”. Status uniwersum, czyli pierwotnej płaszczyzny wydzielania publicznego prawa gospodarczego, w wariancie tym przypadłby prawu gospodarczemu, w jego obrębie konieczne byłoby nadto wydzielenie zbioru norm podlegających zaliczeniu do prawa publicznego. Za publiczne prawo gospodarcze uznany zostałby więc ogół norm prawa gospodarczego o charakterze publicznoprawnym.

Zakres przedmiotowego publicznego prawa gospodarczego $\mathrm{w}$ przedstawionym wariancie modelu kształtującego determinowany byłby $\mathrm{w}$ zasadniczym stopniu ramami przedmiotowymi samego prawa gospodarczego. Ich określenia, podobnie jak w przypadku prawa publicznego, nie sposób dokonać jednak jednoznacznie i precyzyjnie. Sformułowanie stanowiska w przedmiocie kształtu zakresu przedmiotowego prawa gospodarczego wydaje się toteż uwarunkowane uprzednim rozstrzygnięciem problemu charakteru prawa gospodarczego jako gałęzi prawa.

14 W odniesieniu do prawa pracy, zob. m.in. S. Samol, [w:] Prawo pracy, red. Z. Niedbała, Warszawa 2012, s. 269-276; T. Liszcz, Prawo pracy, Warszawa 2014, s. 474-479; L. Florek, Prawo pracy, Warszawa 2015, s. 234-237. W odniesieniu do prawa wyznaniowego zob. m.in. P. Stanisz, [w:] A. Mezglewski, H. Misztal, P. Stanisz, Prawo wyznaniowe, Warszawa 2006, s. 112-117; J. Krukowski, Polskie prawo wyznaniowe, Warszawa 2008, s. 263-268.

15 Za: O. Górniok, [w:] Prawo karne gospodarcze, red. idem, Warszawa 2003, s. 3. 
W sporze o charakter prawa gospodarczego, zapoczątkowanym w nauce radzieckiej w drugiej połowie lat 50 . XX wieku i rychło podjętym również w nauce polskiej, sformułowano dwa zasadnicze, przeciwstawne stanowiska - o samodzielności i odrębności ${ }^{16}$ oraz o kompleksowości ${ }^{17}$ prawa gospodarczego jako gałęzi prawa ${ }^{18}$. W najbardziej radykalnym ujęciu pierwszego z przedstawionych poglądów prawo gospodarcze ujmowane jest jako podstawowa gałąź prawa wyróżniana $\mathrm{w}$ systemie prawa przy zastosowaniu kryteriów odrębności zarówno przedmiotu normowania, jak i metody regulacji, funkcjonująca $\mathrm{w}$ systemie prawa jako struktura równorzędna wobec tradycyjnych gałęzi prawa takich jak prawo cywilne, prawo administracyjne i prawo karne ${ }^{19}$. Drugie ze stanowisk zakłada zaś ujmowanie prawa gospodarczego jako kompleksowej gałęzi prawa wyróżnianej wyłącznie ze względu na jednolitość przedmiotową, której normom przypisać należy podwójną klasyfikację systemową. Wypada je bowiem ujmować zarówno w obrębie prawa gospodarczego, jak i jednej z tradycyjnych gałęzi prawa, dysponujących własnymi metodami regulacji ${ }^{20}$.

Dwoistość stanowisk w przedmiocie charakteru prawa gospodarczego jako gałęzi prawa implikuje konieczność odzwierciedlającego je dwojakiego rozpatrywania drugiego wariantu modelu kształtującego. Postrzegając prawo gospodarcze

16 Za prekursorów koncepcji tej na gruncie radzieckim należy uznać W.S. Tadewosjana, W.P. Jefimoczkina i I.W. Pawłowa - zob. W.S. Tadewosjan, Niekotoryje woprosy sistiemy sowietskogo prawa, „Sowietskoje Gosudarstwo i Prawo” 1956, nr 8, s. 103; W.P. Jefimoczkin, K woprosu o principach postrojenija sistiemy prawa, „Sowietskoje Gosudarstwo i Prawo” 1957, nr 3, s. 91; I.W. Pawłow, O sistiemie sowietskogo socialisticzieskogo prawa, „Sowietskoje Gosudarstwo i Prawo" 1958, nr 11, s. 12. Mimo radykalnie odmiennych uwarunkowań życia gospodarczego w latach 50. XX wieku w Związku Radzieckim oraz współcześnie, które odzwierciedlają się w odmiennej treści norm prawnych regulujących problematykę gospodarczą, wypracowane ówcześnie stanowiska w przedmiocie charakteru prawa gospodarczego wydają się godne uwzględnienia $\mathrm{z}$ uwagi na ich odniesienie do formy, nie zaś materii prawa gospodarczego. Specyfika prawnego unormowania życia gospodarczego zdaje się bowiem występować w znacząco nawet różnych systemach gospodarczych. Koncepcje dotyczące charakteru prawa gospodarczego wysuwane w okresie Związku Radzieckiego stanowią nierzadko punkt wyjścia dla rozważań podejmowanych we współczesnej literaturze rosyjskiej — por. m.in. W.S. Biełych, Prawowoje riegulirowanije priedprinimatielskoj diejatielnosti w Rossii, Moskwa 2005, s. 4-17; O.A. Bieliajewa, Priedprinimatielskoje prawo, Moskwa 2014, s. 11-19.

17 Za kompleksowym charakterem prawa gospodarczego, odwołując się do podziału sformułowanego przez W.K. Rajchiera, wypowiedział się w 1958 r. W.S. Pokrowskij, zob. W.S.Pokrowskij, Obsużdienije woprosow sistiemy sowietskogo prawa i socialisticzieskoj zakonnosti, „Sowietskoje Gosudarstwo i Prawo” 1958, nr 11, s. 127.

18 Zaznaczyć wypada, że silnie reprezentowane było również stanowisko negujące zasadność posługiwania się kategorią prawa gospodarczego w ogólności. Do jego czołowych przedstawicieli należeli m.in. M.D. Szargorodskij i O.S. Joffe — zob. M.S. Szargorodskij, O.S. Joffe, O sistiemie sowietskogo prawa, „Sowietskoje Gosudarstwo i Prawo” 1957, nr 6, s. 105.

19 Ujęcie takie prezentuje W.K. Mamutow, który wyróżnia odrębną metodę regulacji prawa gospodarczego - zob. W.K. Mamutow, Choziajstwiennoje prawo, Kijów 2002, s. 29-32.

20 A. Bator, Użycie normy prawnej w regulacji stosunków gospodarczych, Wrocław 2000, s. 20 .

Prawo 320, 2016

(C) for this edition by CNS 
jako gałąź kompleksową, obejmującą normy dotyczące problematyki gospodarczej wyodrębnione w obszarze podstawowych gałęzi prawa, a zatem - w całym systemie prawa, zakresem przedmiotowym publicznego prawa gospodarczego wypadłoby objąć ogół norm prawnych dotyczących gospodarki o charakterze publicznoprawnym. Tak ujęty zbiór norm przybrałby kształt zakresowo tożsamy z ramami przedmiotowymi publicznego prawa gospodarczego, określonymi według założeń pierwszego wariantu modelu kształtującego. Właściwy publicznemu prawu gospodarczemu w obu przedstawionych ujęciach charakter quasi-kompleksowy w drugim wariancie modelu kształtującego znalazłby uzasadnienie genetyczne. Zakres przedmiotowy publicznego prawa gospodarczego wyznaczony zostałby bowiem w obrębie gałęzi o charakterze kompleksowym poprzez wydzielenie norm prawnych opartych na metodach regulacji właściwych wyłącznie prawu publicznemu ${ }^{21}$.

W literaturze kompleksowe ujęcie prawa gospodarczego jako gałęzi prawa deklarują K. Strzyczkowski22 i T. Demendecki ${ }^{23}$, co prowadzi ich do postrzegania publicznego prawa gospodarczego jako jednego z elementów dualistycznego podziału tak ujmowanej całości. Stanowisko to, nominalnie wpisujące się w drugi wariant modelu kształtującego, nie znajduje jednak odzwierciedlenia w treści opracowań ich autorstwa. Nie obejmują one choćby w zarysie omówienia norm prawa karnego gospodarczego, które, jak wskazano powyżej, bezsprzecznie zawierają się w granicach określonych wyznacznikami „publiczne” i ,gospodarcze"; nie sposób bowiem nie zaliczyć ich do kompleksowo ujmowanego prawa gospodarczego, wątpliwości nie budzi nadto ich publicznoprawny charakter.

Granice węższe niż w przypadku uznawania prawa gospodarczego za gałąź kompleksową należałoby wytyczyć zakresowi przedmiotowemu publicznego prawa gospodarczego, uznawszy prawo gospodarcze za gałąź samodzielną, odrębną wobec prawa cywilnego, prawa administracyjnego i prawa karnego. Zasadniczy paradygmat tego założenia zasadza się na wydzieleniu w systemie prawa zbioru norm dotyczących problematyki gospodarczej, które podlegałyby zaliczeniu

21 Do metod regulacji właściwych prawu publicznemu zaliczyć należy metodę ,,administratywistyczną” i metodę „karnistyczną”, o których piszą m.in. A. Stelmachowski (A. Stelmachowski, Wstęp do teorii prawa cywilnego, Warszawa 1969, s. 17) oraz Z. Ziembiński (Z. Ziembiński, Szkice z metodologii szczegółowych nauk prawnych, Warszawa-Poznań 1983, s. 116-120). Odmienne stanowisko prezentuje A. Bator, który kwestionuje ujmowanie metody „karnistycznej” jako równorzędnej wobec metod „,administratywistycznej” i „,cywilistycznej” (A. Bator, op. cit., s. 53).

${ }^{22}$ K. Strzyczkowski wskazuje, że prawo gospodarcze zostało wyodrębnione ze względu na „kompleksowy przedmiot regulacji prawnej — gospodarkę”. Zakres prawa gospodarczego obejmuje, według tego autora, „wszystkie normy prawne mające zastosowanie w procesie gospodarowania”. K. Strzyczkowski, op. cit., s. 46.

23 T. Demendecki, wskazując na kompleksowe usytuowanie prawa gospodarczego w systemie prawa, zalicza do jego norm ,wszystkie normy prawne mające zastosowanie w procesie gospodarowania". Autor jako kompleksową gałąź prawa określa również prawo publiczne gospodarcze. T. Demendecki, op. cit., s. 10-11. 
do prawa gospodarczego, z wyłączeniem możliwości równoczesnego uznawania ich za należące nadto do innych podstawowych gałęzi prawa. Określenie przynależności systemowej poszczególnych norm związanych z zagadnieniami gospodarczymi wymagałoby więc zastosowania szczegółowo oznaczonych kryteriów, które mogłyby odnosić się zarówno do swoistości metody regulacji (przy uznaniu istnienia odrębnej metody regulacji prawa gospodarczego), jak i swoistości przedmiotowej. W przedstawionym ujęciu zakres przedmiotowy publicznego prawa gospodarczego stanowiłby ogół norm zaliczonych na podstawie określonych kryteriów do prawa gospodarczego (a przez to niepodlegających równoczesnej klasyfikacji w ramach prawa cywilnego, prawa administracyjnego i prawa karnego), mających ponadto charakter publicznoprawny.

Stanowisko zakładające samodzielność i odrębność gałęziową prawa gospodarczego nie zostało explicite wyrażone we współczesnych opracowaniach. Podejmując jednak zabieg o charakterze postracjonalizującym ${ }^{24}$, mający na celu aposterioryczne skonstruowanie uzasadnionego systemowo powiązania nazwy działu prawa ,publiczne prawo gospodarcze” z przypisywanym mu w literaturze zakresem przedmiotowym, rozważyć należałoby posłużenie się rozumowaniem indukcyjnym, w przypadku którego ramy publicznoprawnej części prawa gospodarczego jako samodzielnej i odrębnej gałęzi prawa zostałyby określone na podstawie treści merytorycznych przedstawianych $\mathrm{w}$ opracowaniach $\mathrm{w}$ zamierzeniu całościowo przedstawiających zagadnienia publicznego prawa gospodarczego. Zabieg taki zasadzałby się na założeniu, zgodnie z którym omówienie przez autorów określonego wolumenu norm prawnych (o charakterze bezsprzecznie publicznoprawnym), przedstawianego jako całość zagadnień publicznego prawa gospodarczego, stanowi wyraz uznania przez nich wolumenu tego za całościowy zbiór norm ze względu na określone kryteria podlegających zaliczeniu do prawa gospodarczego (nie zaś do innych samodzielnych i odrębnych gałęzi prawa), mających ponadto charakter publicznoprawny. Przedstawiony zabieg przypisujący autorom opracowań niewyrażone explicite przyjęcie określonych kryteriów klasyfikowania norm jako należących do prawa gospodarczego, a przez ich publicznoprawny charakter - również do publicznego prawa gospodarczego, pozwalałby na skonstruowanie uzasadnienia braku ujęcia w opracowaniach omówienia norm prawnokarnych dotyczących problematyki gospodarczej. Uznać należałoby bowiem, że brak ujęcia w opracowaniach norm prawnokarnych wynika z dokonanego przez autorów ustalenia, że normy te - wskutek przyjętych kryteriów klasyfikacyjnych — podlegają zaliczeniu do prawa karnego, co wyklucza możliwość uznania ich za objęte zakresem również prawa gospodarczego oraz, w konsekwencji, publicznego prawa gospodarczego.

24 Pojęcia „zabiegów postracjonalizujących” użyły L. Lisiakiewicz i A. Turska dla określenia prób skonstruowania naukowego uzasadnienia kształtu systemu prawa ukształtowanego w rozwoju historycznym - zob. L. Lisiakiewicz, A. Turska, $W$ kwestii dyferencjacji $i$ integracji systemu prawa, „Państwo i Prawo” 1971, nr 5, s. 682.

Prawo 320, 2016

(C) for this edition by CNS 
Reasumując rozważania dotyczące drugiego wariantu modelu kształtującego, zakładającego ujmowanie publicznego prawa gospodarczego jako ogółu norm prawa gospodarczego o charakterze publicznoprawnym, podkreślić należy, że adekwatność odniesienia go do zakresu przedmiotowego publicznego prawa gospodarczego w kształcie prezentowanym w literaturze zależy od stanowiska przyjętego wobec charakteru prawa gospodarczego jako gałęzi prawa. Postrzeganie prawa gospodarczego jako gałęzi kompleksowej implikuje utożsamienie zakresu przedmiotowego publicznego prawa gospodarczego $\mathrm{w}$ przedstawionym ujęciu z zakresem konstruowanym według założeń pierwszego wariantu modelu kształtującego. Sprawia, że publicznemu prawu gospodarczemu przypisać należałoby status działu quasi-kompleksowego. Wiąże się to zaś z koniecznością ujmowania w jego ramach norm prawa karnego gospodarczego, co nie znajduje jednak odzwierciedlenia w literaturze. Wykreowanie adekwatnego systemowo powiązania nazwy działu prawa ,publiczne prawo gospodarcze” z jego zakresem przedmiotowym przedstawianym w opracowaniach wydaje się możliwe przy zastosowaniu drugiej koncepcji statusu prawa gospodarczego jako gałęzi prawa - koncepcji ujmującej prawo gospodarcze jako gałąź samodzielną i odrębną, obejmującą normy niepodlegające równoczesnemu zaliczeniu do innych gałęzi. W celu zarysowania adekwatnego powiązania założyć należy, że w ramach współczesnych opracowań ujęto całość intencjonalnie wyodrębnionych przy wykorzystaniu określonych kryteriów norm prawa gospodarczego (niezaliczanych przy tym do prawa cywilnego, prawa administracyjnego i prawa karnego), które cechują się charakterem publicznoprawnym.

\section{IV}

Obok kształtującego modelu relacji wyznacznika „publiczne” do zakresu przedmiotowego publicznego prawa gospodarczego wyróżnić należy model opisowy. W modelu tym wyznacznik ,publiczne” pozbawiony byłby roli determinującej kształt zakresu przedmiotowego publicznego prawa gospodarczego. Wskazywałby on jedynie wspólną cechę norm prawnych ujmowanych w zbiór nazwany „publicznym prawem gospodarczym”, którego zakres byłby ustalany wyłącznie na podstawie ram wyznaczonych zasięgiem zjawiska ujętego w definicji wskazanego działu prawa. Zakresu przedmiotowego publicznego prawa gospodarczego nie należałoby więc ujmować jako obszaru w systemie prawa wydzielonego przy zastosowaniu wyznaczników zawartych w nazwie działu prawa; zakres ten wypadłoby określać raczej jako zbiór norm prawnych dotyczących problematyki wskazanej w definicji działu. Znaczenie relewantne dla określenia zakresu przedmiotowego publicznego prawa gospodarczego należałoby więc przypisać jego definicji, nazwa zaś zyskałaby znaczenie jedynie wtórne. Charakter zawartych w niej wyznaczników „,publiczne” oraz „gospodarcze” wypadłoby zatem określić 
jako aposterioryczny, opisujący cechy norm zawartych w zbiorze wyodrębnionym na podstawie brzmienia definicji.

Zjawiskiem uznawanym powszechnie w nauce polskiej za definiujące dla publicznego prawa gospodarczego jest, w stopniu szczegółowym różnie ujmowana, interwencja państwa w sferze gospodarki ${ }^{25}$. Zakres przedmiotowy analizowanego działu prawa stanowić więc powinien całokształt norm prawnych tej interwencji dotyczących. Wydaje się, że przypisanie temu całokształtowi en bloc cechy „publiczne" jest zabiegiem trafnym. Jakkolwiek nie sposób wskazać jednego uniwersalnego kryterium przeprowadzenia podziału pomiędzy prawem publicznym i prywatnym, normy dotyczące interwencji państwa w sferze gospodarki należy zaklasyfikować jako normy prawa publicznego na podstawie wszechstronnej analizy szeregu kryteriów wskazywanych w nauce ${ }^{26}$. Odnosząc się do dualistycznego podziału kryteriów wyróżniania prawa publicznego i prywatnego sformułowanego przez J. Nowackiego, godzi się zaznaczyć, że normy dotyczące interwencji państwa w sferze gospodarki odpowiadać będą kryteriom o charakterze zarówno obiektywnym, jak i subiektywnym ${ }^{27}$. W planie obiektywnym publicznoprawna istota wskazanego zbioru norm wynika m.in. $\mathrm{z}$ ich specyfiki podmiotowej i przedmiotowej. Specyfika podmiotowa wyraża się w adresowaniu przedmiotowych norm do państwa oraz $\mathrm{w}$ udziale państwa w stosunkach prawnych powstających w rezultacie ich zastosowania; specyfika zaś przedmiotowa zasadza się na oparciu stosunków prawnych wynikających z analizowanych norm o atrybut władczości, implikujący podporządkowanie jednej ze stron stosunku drugiej stronie ${ }^{28}$. W perspektywie subiektywnej za zaliczeniem norm dotyczących interwencji państwa w sferze gospodarki do prawa publicznego przemawia niewątpliwie ustanawianie ich w celu realizacji interesu publicznego, nie zaś w celu urzeczywistniania interesów poszczególnych jednostek ${ }^{29}$.

Nie wydaje się budzić wątpliwości, że publicznemu prawu gospodarczemu, wyodrębnianemu na podstawie ujętego w jego definicji zjawiska interwencji państwa w sferze gospodarki, a priori przypisać należałoby cechę quasi-kompleksowości, wyrażającą się, podobnie jak w ujęciach prezentowanych uprzednio, w objęciu jego ramami ogółu norm wyodrębnianych ze względu na jednolitość przedmiotową, opartych na metodach regulacji właściwych prawu publicznemu. Supozycja ta nie znajduje jednak odzwierciedlenia w literaturze z uwagi na wskazywane już pomijanie $\mathrm{w}$ treści opracowań $\mathrm{w}$ zamierzeniu całościowo przedstawiających zagadnienia publicznego prawa gospodarczego omówienia norm prawa karnego gospodarczego (a także m.in. prawa podatkowego), które wydają się

25 Tak m.in. C. Kosikowski, op. cit., s. 43; Prawo gospodarcze publiczne..., s. 5; J. Grabowski, op. cit., s. 20.

26 S. Wronkowska, op. cit., s. 112.

27 J. Nowacki, op. cit., s. 94.

28 Ibidem, s. 77-86; S. Wronkowska, op. cit., s. 112.

29 J. Nowacki, op. cit., s. 95-96.

Prawo 320, 2016

(C) for this edition by CNS 
w pełni wpisywać w ramy wyznaczone zasięgiem zjawiska interwencji państwa w sferze gospodarki i publicznoprawnym charakterem metody regulacji.

Niewątpliwie interwencja państwa w sferze gospodarki przybierać może postaci o kształcie wysoce zróżnicowanym — definiując kompetencje interwencyjne państwa w gospodarce, J. Grabowski wskazuje, że ich istotę stanowi korygowanie lub ograniczanie działania czystego mechanizmu rynkowego bez względu na formę i charakter prawny ${ }^{30}$. Bezsprzecznie zaś funkcjonowanie w systemie prawa przepisów karnych mających na celu ochronę obrotu gospodarczego, ze swej prawnokarnej istoty powiązanych z sankcją o najsurowszym charakterze, powoduje korektę działania czystego mechanizmu rynkowego, który — jak wskazuje R. Zawłocki — „niejako samoistnie rodzi zjawiska patologiczne”31. Choć przez wzgląd na postulat subsydiarności norm prawa karnego regulacje prawa karnego gospodarczego nie wyznaczają co do zasady autonomicznych wzorów zachowań, niezależnych od wzorów określonych normami materialnego administracyjnego prawa gospodarczego, doniosłość wykorzystania przez ustawodawcę norm prawnokarnych w sferze regulacji gospodarki wydaje się polegać na stworzeniu instrumentów istotnie wzmacniających, lub wręcz wymuszających, kształtowanie ,prawidłowych postaw gospodarczych osób prowadzących działalność o charakterze gospodarczym"32. Kształtowanie postaw tych wydaje się zaś doniosłą rolą ustawodawcy z uwagi na szczególne niebezpieczeństwo ich zaburzenia wskutek działania czystego mechanizmu rynkowego opartego na mogącej skłaniać do zachowań sprzecznych z prawem intensyfikacji działań mających na celu maksymalizację zysku. Trudno więc znaleźć racjonalne przyczyny, dla których normom prawa karnego gospodarczego, mającym charakter niezaprzeczalnie publicznoprawny, należałoby odmówić statusu instrumentu interwencji państwa w sferze gospodarki.

Warto zaznaczyć, że w literaturze wskazuje się również na podejmowanie przez państwo ingerencji w stosunki gospodarcze za pomocą podatków S. Dolata wśród podstawowych funkcji podatków wymienia funkcję gospodarczą, polegającą na ,wykorzystaniu podatku jako środka oddziaływania na gospodarkę" 33 . R. Mastalski zaznacza zaś, że „podatki mogą być w pewnym zakresie wykorzystywane jako instrumenty oddziaływania na gospodarkę, pod warunkiem jednak, że ich działanie jest zgodne $\mathrm{z}$ rynkowymi mechanizmami funkcjonowania gospodarki"34. W związku z powyższymi konstatacjami zasadne byłoby ujęcie pewnej części norm prawa podatkowego w obrębie ram przedmiotowych wyznaczonych zasięgiem zjawiska interwencji państwa w sferze gospodarki.

30 J. Grabowski, op. cit., s. 23.

31 R. Zawłocki, [w:] System prawa handlowego. Prawo karne gospodarcze, red. idem, t. 10, Warszawa 2012, s. 16-17.

32 Ibidem, s. 17-19.

33 S. Dolata, Podstawy wiedzy o polskim systemie podatkowym, Warszawa 2013, s. 85.

34 R. Mastalski, Prawo podatkowe, Wrocław 2012, s. 10. 
Mając powyższe na względzie, zauważyć wypada, że opisowy model relacji wyznacznika ,publiczne” do zakresu przedmiotowego publicznego prawa gospodarczego, oparty na aposteriorycznym przypisaniu wyznacznika ,publiczne" zbiorowi norm wyodrębnionemu na podstawie zasięgu ujętego w definicji tego działu prawa zjawiska interwencji państwa w sferze gospodarki, należy uznać za uzasadniony in abstracto, przez wzgląd na bezsprzecznie publicznoprawny status wydzielanych we wskazany sposób norm. In concreto nie znajduje on jednak odzwierciedlenia w literaturze $\mathrm{z}$ uwagi na pomijanie w opracowaniach w zamierzeniu całościowo przedstawiających zagadnienia publicznego prawa gospodarczego omówienia norm prawa karnego gospodarczego i norm prawa podatkowego dotyczących problematyki gospodarczej. Normy te należy bowiem uznać za instrument interwencji państwa w sferze gospodarki, o doniosłości istotnej — w odniesieniu do prawa karnego gospodarczego - szczególnie z uwagi na wysoki stopień jego potencjalnej skuteczności w zapobieganiu naruszeniom prawa, których znaczne ryzyko wystąpienia w obrocie gospodarczym wiąże się z wynikającą z czystego mechanizmu rynkowego wszechstronną intensyfikacją dążenia do maksymalizacji zysku.

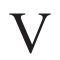

Konstruowanie refleksji objętych niniejszym opracowaniem uwarunkowane zostało dążeniem do ustalenia znaczenia wyznacznika ,publiczne” w nazwie działu prawa ,publiczne prawo gospodarcze”, uznanego za zagadnienie istotne w głównej mierze $\mathrm{z}$ uwagi na konsekwentne pomijanie omówienia zaliczanych bezsprzecznie do prawa publicznego norm prawa karnego gospodarczego w treści opracowań w zamierzeniu całościowo przedstawiających zagadnienia publicznego prawa gospodarczego. W celu realizacji wskazanego założenia dokonano wyróżnienia teoretycznych modeli relacji wyznacznika „publiczne” do zakresu przedmiotowego publicznego prawa gospodarczego i odniesiono je do kształtu zakresu przedmiotowego publicznego prawa gospodarczego prezentowanego w literaturze. W modelu kształtującym wyznacznikowi ,ppubliczne”, wraz z wyznacznikiem ,gospodarcze”, przypisano rolę determinującą, określającą zakres przedmiotowy publicznego prawa gospodarczego. W modelu opisowym wyznacznik ,publiczne” pełnił zaś funkcję jedynie charakteryzującą zespół norm wyodrębnionych uprzednio w oparciu o treść definicji publicznego prawa gospodarczego sformułowaną przez doktrynę.

Dokonane obserwacje i ustalenia wskazują, że na skonstruowanie uzasadnionego systemowo powiązania wyznacznika ,publiczne” z przedstawianym w literaturze zakresem przedmiotowym publicznego prawa gospodarczego pozwala jedynie zastosowanie modelu kształtującego, w wariancie uznającym publiczne prawo gospodarcze za element dualistycznego podziału uniwersum w postaci pra- 
wa gospodarczego ujmowanego jako gałąź samodzielna i odrębna wobec prawa cywilnego, prawa administracyjnego i prawa karnego. Brak objęcia norm prawa karnego gospodarczego zakresem przedmiotowym publicznego prawa gospodarczego wypada na podstawie rozumowania indukcyjnego uznać, w ramach zabiegu o charakterze postracjonalizującym, za uzasadniony zaliczeniem wskazanej kategorii norm do prawa karnego, co z uwagi na odrębną i równorzędną wobec prawa karnego pozycję prawa gospodarczego w systemie prawa wyklucza ich równoczesne ujmowanie w obrębie prawa gospodarczego, a wskutek tego — również w obrębie publicznego prawa gospodarczego.

\section{Comments on the public law framework for the scope of public economic law}

\section{Summary}

The evolution of administrative economic law into public economic law should cause extension of the scope of this section of law, corresponding to its name containing two determinants. However, the scope of public economic law presented in contemporary Polish comprehensive manuals of public economic law does not contain any references to economic criminal law, which is undoubtedly a section of law situated within the confines of public law. In order to determine the meaning of the determinant "public" in the name "public economic law" two models were proposed. In a "shaping" model the determinant "public", together with the determinant "economic", defines the scope of public economic law. Only accepting the view on economic law as an independent branch of law and - consequently - the view on public economic law as a divisive factor of the economic law as an independent branch of law allows to justify an omission of economic criminal law provisions which should be included into criminal law. Regarding economic law as an independent branch of law does not entitle one to include such provisions into it if they are classified as a part of another independent branch of law - in this case: criminal law. Another model is a "descriptive" one, in which the determinant "public" does not define the scope of public economic law - the scope is determined by the definition of public economic law. The only role of the determinant "public" is to describe a category of provisions that are included in public economic law. The model, however, does not justify the omission of economic criminal law provisions in the manuals because of a broad shape of the definition of public economic law presented in Polish literature. of law.

Keywords: public economic law, economic law, public law, economic criminal law, branch

\section{Bibliografia}

Bator A., Użycie normy prawnej w regulacji stosunków gospodarczych, Wrocław 2000.

Bieliajewa O.A., Priedprinimatielskoje prawo, Moskwa 2014.

Biełych W.S., Prawowoje riegulirowanije priedprinimatielskoj diejatielnosti $w$ Rossii, Moskwa 2005.

Borkowski A. et al., Administracyjne prawo gospodarcze, Wrocław 2009.

Demendecki T., Zarys polskiego prawa publicznego gospodarczego, Lublin 2011.

Dolata S., Podstawy wiedzy o polskim systemie podatkowym, Warszawa 2013.

Prawo 320, 2016

(C) for this edition by CNS 
Florek L., Prawo pracy, Warszawa 2015.

Hoc S., Prawo administracyjne gospodarcze. Wybrane zagadnienia, Warszawa 2009.

Jefimoczkin W.P., $K$ woprosu o principach postrojenija sistiemy prawa, „Sowietskoje Gosudarstwo i Prawo" 1957, nr 3 .

Kieres L., Konstytucyjne publiczne prawo gospodarcze, „Ruch Prawniczy, Ekonomiczny i Socjologiczny” 2014, nr. 2.

Kosikowski C., Publiczne prawo gospodarcze Polski i Unii Europejskiej, Warszawa 2010.

Krukowski J., Polskie prawo wyznaniowe, Warszawa 2008.

Lisiakiewicz L., Tuska A., W kwestii dyferencjacji i integracji systemu prawa, „Państwo i Prawo” 1971, z. 5.

Liszcz T., Prawo pracy, Warszawa 2014.

Mamutow W.K., Choziajstwiennoje prawo, Kijów 2002.

Mastalski R., Prawo podatkowe, Wrocław 2012.

Mezglewski A., Misztal H., Stanisz P., Prawo wyznaniowe, Warszawa 2006.

Nowacki J., Prawo publiczne - prawo prywatne, Katowice 1992.

Pawłow I.W., O sistiemie sowietskogo socialisticzieskogo prawa, „Sowietskoje Gosudarstwo i Prawo" 1958 , nr 11.

Pokrowskij W.S., Obsuzdienije woprosow sistiemy sowietskogo prawa i socialisticzieskoj zakonnosti, „Sowietskoje Gosudarstwo i Prawo” 1958, nr 11.

Prawo gospodarcze publiczne, red. A. Powałowski, Warszawa 2015.

Prawo karne gospodarcze, red. O. Górniok, Warszawa 2003.

Prawo pracy, red. Z. Niedbała, Warszawa 2012.

Publiczne prawo gospodarcze, Warszawa 2013, („System Prawa Administracyjnego”, red. J. Grabowski, L. Kieres, A. Walaszek-Pyzioł, t. 8a i 8b).

Publiczne prawo gospodarcze, red. J. Olszewski, Warszawa 2015.

Publiczne prawo gospodarcze. Zarys wyktadu, red. R. Blicharz, Warszawa 2015.

Rabska T., Prawo administracyjne a publiczne prawo gospodarcze (kilka dyskusyjnych refleksji), [w:] Między tradycją a przyszłościa w nauce prawa administracyjnego. Księga jubileuszowa dedykowana Profesorowi Janowi Bociowi, red. J. Supernat, Wrocław 2009.

Rabska T., Rozwój nauczania publicznego prawa gospodarczego — przyczynek do dyskusji, „Przegląd Ustawodawstwa Gospodarczego" 2005, nr 9.

Snażyk Z., Szafrański A., Publiczne prawo gospodarcze, Warszawa 2013.

Stelmachowski A., Wstęp do teorii prawa cywilnego, Warszawa 1969.

Strzyczkowski K., Prawo gospodarcze publiczne, Warszawa 2011.

System prawa handlowego. Prawo karne gospodarcze, t. 10, red. R. Zawłocki, Warszawa 2012.

Szargorodskij M.D., Joffe O.S., O sistiemie sowietskogo prawa, „Sowietskoje Gosudarstwo i Prawo" 1957, nr 6.

Tadewosjan W.S., Niekotoryje woprosy sistiemy sowietskogo prawa, „Sowietskoje Gosudarstwo i Prawo" 1956, nr 8.

Wronkowska S., Podstawowe pojęcia prawa i prawoznawstwa, Poznań 2005.

Ziembiński Z., Szkice z metodologii szczegółowych nauk prawnych, Warszawa-Poznań 1983. 